\title{
Anti-amyloid Monoclonal Antibody NEOD001
}

National Cancer Institute

\section{Source}

National Cancer Institute. Anti-amyloid Monoclonal Antibody NEOD001. NCI Thesaurus.

Code C106248.

A monoclonal antibody against amyloid with potential use in the treatment of amyloid light chain ( $\mathrm{AL}$ ) and $\mathrm{AA}$ amyloidosis. Upon intravenous administration, anti-amyloid monoclonal antibody NEOD001 specifically binds to amyloid fibrils. This prevents the formation of amyloid deposits in certain organs and facilitates their clearance. It also reduces the level of amyloid deposits in organs and prevents organ dysfunction. 